\section{Major appointments at stake}

Peter Pockley reports from Sydney on the important jobs now open on the Australian science scene

WhILE the organisational structure of Australian government-financed science and advisory machinery is still being sorted out, the government has the opportunity of making some even more significant changes through the clean sweep of senior science appointments which have to be made between now and the middle of next year. The jobs at stake are the Chairmanship of CSIRO, the Chairmanship of the Australian Atomic Energy Commission (AAEC), and the Permanent Head (Secretary) of the Department of Science. Between them, these positions control over $\$ 200$ million of funds, well over the total of all other government research and development funds put together. Appointments to the three positions are in the gift of the government, formally by different ministers, but in practice the Prime Minister, Mr Malcolm Fraser, is expected to take a strong hand in all selections.

Dr Jerry Price, the Chairman of CSIRO, is now in his last year of office; he will reach the retiring age of 65 next March. A committee to examine the filling of the vacancy has been appointed, reportedly by $\mathrm{Mr}$ Fraser himself even though CSIRO reports to the Minister of Science, Senator Iames Webster. The committee is operating very privately, but is understood to be chaired by a leading academic. Not only has it been charged with recommending a prescription for the ideal candidate, but it is also looking critically at the structure of the CSIRO Executive and its decisionmaking processes.

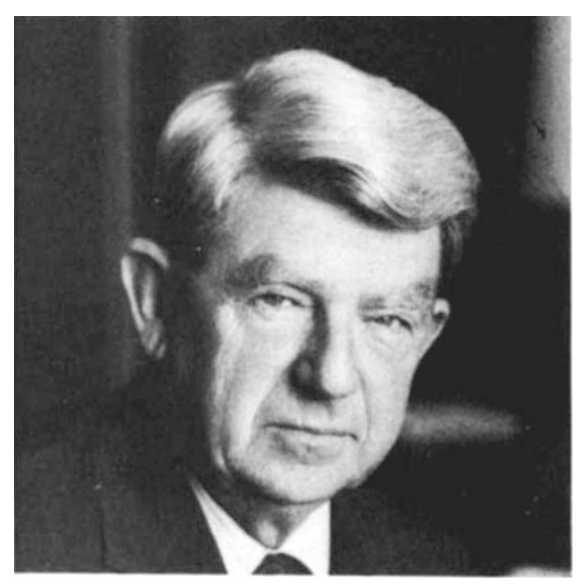

Sir Hugh Ennor: retiring early?
CSIRO operates as a statutory authority under its own Act of Parliament, the Science and Industry Act. The Executive is the body responsible under the legislation for CSIRO's activities, and much interest attaches to appointments to the Executive and its terms of reference. The Labor Government had determined last year to allow the staff of CSIRO to elect one of the part-time members of the Executive, but the Liberals snuffed out the staff's hopes in this regard by getting elected to Government just before the election process had gone into the period of no-return. The part-timer whose retirement from the Executive was creating the vacancy for a staff member has had his term extended for a short period by the Liberal Government, thereby avoiding the need for a decision on the politically sensitive question of formal staff involvement on the boards of statutory authorities.

The CSIRO staff are making their views known to the committee on this and other matters of contention within the organisation. One proposal emerging is the possibility of restructuring the 9-member Executive (Chairman, 4 full-timers, 4 part-timers) into a "troika" of Chairman and two fulltimers concerned with broad policy issues and an "outer" executive charged with administrative functions. The key to any major changes is the appointment of the Chairman. Dr Price was promoted to the Chairmanship from the Executive in 1970; this time the field is probably wide open, including to outsiders.

Sir Hugh Ennor, Secretary of the Department of Science, will reach retiring age of 65 in October 1977. Like many senior Australian Government public servants over 60 , though, there will shortly be a prospect for earlier retirement with the introduction of a new superannuation scheme in July. With the Department he established in 1972 currently under threat of abolition, Sir Hugh Ennor can be expected to fight to go out with full Secretary status. Absorption of his Department within another one before his retirement would be a bitter pill, and Sir Hugh is not a man to be lightly put down.

Nonetheless, a decision will have to be made within a year about who is to head the administration of the operational branches and sections presently within the Department of Science, whether the Department exists as a separate entity or, for example, is recombined with the Department of Education. This appointment is highly likely to go to a senior public servant. Mr Fraser has set himself against outside appointments to permanent headships following his inheritance of some of $\mathrm{Mr}$ Whitlam's appointees, two of whom are still languishing on the socalled "unattached list" where they draw their nice salaries and do nothing while awaiting appointments which never come.

The Chairmanship of the AAEC is vacant because of the sudden death on the job earlier in the year of Mr Bill Boswell, who had been full-time Chairman since 1972. The AAEC has been left in a very uncertain position, since both the Labor and the Liberal Governments had failed to appoint Commissioners to fill two part-time vacancies in the Commission of five. With Mr Boswell's death, the AAEC is left with only two part-timers. The previous Vice-Chairman, Sir Lenox Hewitt, is filling in as Acting Chairman while also holding down his full-time post as Chairman of Qantas. Professor Harry Messel, the other part-timer, a strong contender for the Chairmanship given more time under Labor, is probably now a non-starter on grounds of having been too closely associated with the former Labor Minister, Mr Rex Connor. If so, the appointment will have to come from outside.

The Minister for National Resources responsible for the AAEC is the Leader of the Country Party and Deputy Prime Minister, Mr Doug Anthony. A strong man who will want to appoint his own AAEC Chairman, Mr Anthony will nevertheless have to defer to Mr Fraser because of the Prime Minister's newly won influence over the whole science scene through the Australian Science and Technology Council which reports direct to him. While ASTEC does not have appointments advice within its charter, its membership does contain one or two likely contenders for the CSIRO or AAEC jobs.

Overseas aspirants, please note: the public servant pecking order in Canberra is determined largely by relative salaries, but there are some other interesting comparisons. The Chairman of AAEC currently receives 31,000 Australian dollars. Next is the Chairman of CSIRO on only $\$ 32,500$ ("only" because the CSIRO budget is roughly 10 times that of AAEC). The Secretary of the Department of Science receives $\$ 35,000$, for running an operation about a third of CSIRO's in terms of money and staff.

- Stop press: Professor Donald W. George, Vice-Chancellor of the University of Newcastle, has been appointed part-time Chairman of the AAEC. The other two AAEC vacancies have also been filled. 